
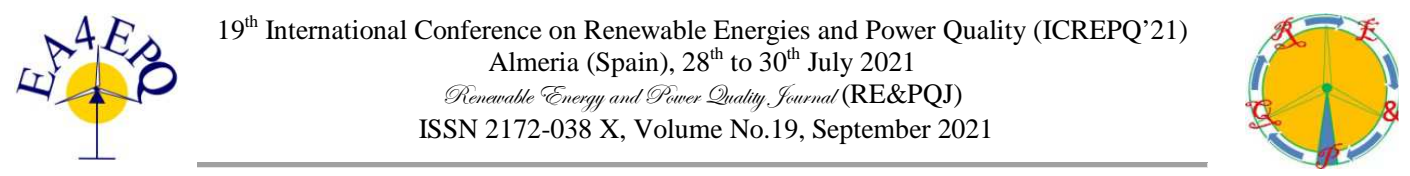

\title{
High energy-efficient electrical drive with multilevel inverter and wide- bandgap power semiconductors
}

\author{
R. Mecke \\ Department of Automation and Computer Sciences \\ Harz University of Applied Sciences \\ Friedrichstraße 57-59, D-38855 Wernigerode (Germany) \\ Phone/Fax number:+49 3943659 831, e-mail: rmecke@hs-harz.de
}

\begin{abstract}
Multilevel inverters are an alternative for electrical drives with DC link voltage between 560 and $750 \mathrm{~V}$. In this voltage range new wide-bandgap power switches (SiC MOSFET, GaN FET) are available. The paper analyses three-, four-, five- and seven-level inverters. A simulation model of the drive system, including the $11 \mathrm{~kW}$ induction motor and motor filter is developed. By replacing IGBTs with SiC FETs, the twolevel inverter achieved a loss reduction of $59 \%$ at $25^{\circ} \mathrm{C}$ and $150{ }^{\circ} \mathrm{C}$ at nominal motor operation point. By using the five-level inverter with GaN FETs, a further loss reduction of $9 \%$ only at low junction temperature is possible. With a higher number of inverter levels, the size of the motor filter can be reduced. With five inverter levels and $40 \mathrm{kHz}$ switching frequency volume and weight can be reduced by $86 \%$ and $78 \%$ respectively. The overall efficiency of the drive system achieves $98.5 \%$ at $25{ }^{\circ} \mathrm{C}$ and $98.1 \%$ at $150{ }^{\circ} \mathrm{C}$. Compared to the state of the art (two-level with IGBTs with $5 \mathrm{kHz}$ ), this is an improvement of $2.1 \%$ at $25^{\circ} \mathrm{C}$ and $2.7 \%$ at $150{ }^{\circ} \mathrm{C}$.
\end{abstract}

Key words. Energy efficiency, Multilevel inverter, Wide-bandgap semiconductor, Silicon Carbide, Gallium Nitride.

\section{Introduction}

The energy efficiency of electrical drives is becoming more and more important in the last years. The rapid growth in world energy prices and consumption force the electrical drive companies to develop energy saving features for electrical drives systems. Multilevel inverters are well established for medium voltage applications to divide high voltage into smaller voltage steps. The progress in research and development of low-voltage power semiconductors (e.g. SiC MOSFETs, GaN FETs) leads to the idea to extend the application of multilevel inverters from the medium to the low voltage range (DC link voltage: 560 to $750 \mathrm{~V}$ ). Multilevel topologies could outperform the classical two-level inverter with fewer conduction and switching losses and increase the energy efficiency. Further advantages of multilevel topologies are: reduction of voltage transients at the motor windings especially with long shielded motor cables, reduced stresses on the power switches, lower harmonic distortion content in the output voltage and current, smaller output filter and inverter size. Because of fewer switching losses the switching frequency of the inverter can be increased to minimize the losses in the induction motor. Multilevel inverters are predestined for e-mobility applications, because its focus is high power density, high efficiency and large battery range.

\section{Multilevel Inverter}

The most popular topology for multilevel inverters is the neutral-point-clamped (NPC) three-level inverter, which is shown in Fig. 1. This three-level inverter can be equipped with $600 \mathrm{~V}$-switches instead of $1200 \mathrm{~V}$-switches, which are used for two-level inverters. $600 \mathrm{~V}$-switches have lower conduction and switching losses; therefore the three-level inverter enables an improvement of the inverter efficiency.

Further improvement of energy efficiency can be achieved with multilevel inverters with a higher number of levels (four, five or seven), because the blocking voltages of the switches can be reduced (e.g. $400 \mathrm{~V}$ for four level, $300 \mathrm{~V}$ for five level, $200 \mathrm{~V}$ for seven level). Fig. 2 shows the bridge legs of the four-level and five-level inverter.

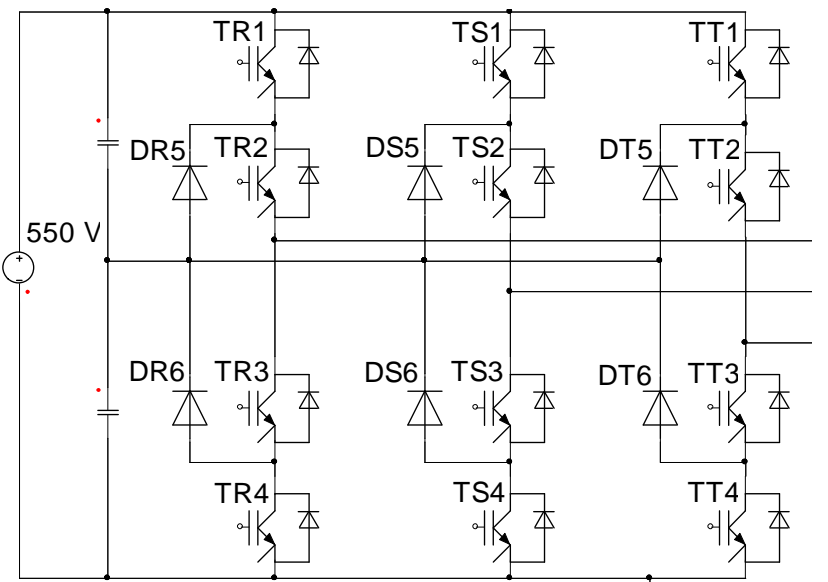

Fig. 1. Three-level neutral-point-clamped (NPC) inverter. 


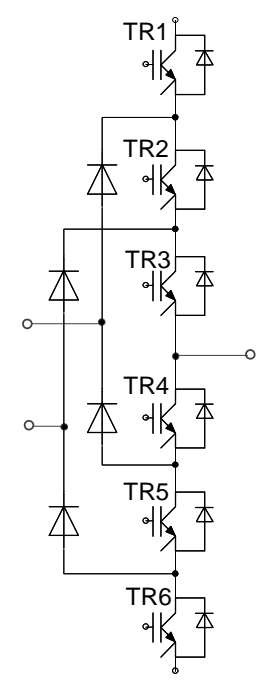

Fig. 2. Bridge legs of the four-level and five-level NPC inverter.

\section{A. Conduction and Switching Losses}

For estimation of conduction and switching losses $\left(\mathrm{P}_{\mathrm{VL}}+\mathrm{P}_{\mathrm{VS}}\right)$ a simulation model was developed that can be integrated into the model of the complete induction motor drive system. To simulate the conduction losses, the power semiconductors (IGBT, SiC MOSFET, GaN FET, diode) are provided with their respective static characteristics $I_{C}=f\left(U_{C E}\right)$. The mean value of the power over a period of the motor frequency is formed from the time curves of voltage and current at each power semiconductor; this corresponds to the conduction losses. Dynamic models of the power semiconductors are usually required to simulate the switching losses. These are insufficiently available, complex to parameterize and require very small simulation time steps (less than $1 \mathrm{~ns}$ ). The new idea is to simulate the switching losses by means of a static model. This allows a much larger simulation time step (100 to $500 \mathrm{~ns}$ ) to be used. In addition, the required parameters are the usual data sheet information from power semiconductor manufacturers. The simulation of conduction and switching losses was done for a $11 \mathrm{~kW}$ high-efficiency induction motor with the best $100 \mathrm{~V}$ to $1200 \mathrm{~V}$ power electronic switches (IGBTs, SiC MOSFETs, GaN FETs) on the market (Tab. I).

Table I. - Power Switches for Multilevel Inverters

\begin{tabular}{|c|c|c|c|c|}
\hline \multirow{2}{*}{$\begin{array}{l}\text { Two - } \\
\text { level }\end{array}$} & Si IGBT & $\begin{array}{c}\text { SK50GD } \\
\text { 12T4T }\end{array}$ & $\begin{array}{c}1200 \mathrm{~V} \\
50 \mathrm{~A}\end{array}$ & $\begin{array}{c}\text { 2L- } \\
\text { IGBT }\end{array}$ \\
\hline & $\begin{array}{c}\text { SiC } \\
\text { MOSFET }\end{array}$ & $\begin{array}{c}\text { CCS050M } \\
12 \mathrm{CM} 2\end{array}$ & $\begin{array}{l}1200 \mathrm{~V} \\
25 \mathrm{~m} \Omega\end{array}$ & $\begin{array}{l}2 \mathrm{~L}- \\
\mathrm{SiC}\end{array}$ \\
\hline \multirow{3}{*}{$\begin{array}{l}\text { Three } \\
\text {-level }\end{array}$} & Si IGBT & $\begin{array}{c}\text { SK50MLI } \\
066\end{array}$ & $\begin{array}{c}600 \mathrm{~V} \\
50 \mathrm{~A}\end{array}$ & $\begin{array}{l}3 \mathrm{~L}- \\
\text { IGBT }\end{array}$ \\
\hline & $\begin{array}{c}\mathrm{SiC} \\
\text { MOSFET }\end{array}$ & $\begin{array}{l}\text { C3M00 } \\
30090 \mathrm{~K} \\
\end{array}$ & $\begin{array}{l}900 \mathrm{~V} \\
30 \mathrm{~m} \Omega \\
\end{array}$ & $\begin{array}{l}\text { 3L- } \\
\mathrm{SiC}\end{array}$ \\
\hline & GaN FET & GS66516 & $\begin{array}{l}650 \mathrm{~V} \\
25 \mathrm{~m} \Omega \\
\end{array}$ & $\begin{array}{l}3 \mathrm{~L}- \\
\mathrm{GaN}\end{array}$ \\
\hline $\begin{array}{l}\text { Four- } \\
\text { level }\end{array}$ & GaN FET & $\begin{array}{c}2 \times 2 \| \\
\text { EPC } 2034 C\end{array}$ & $\begin{array}{c}2 \times 200 \mathrm{~V} \\
4 \mathrm{~m} \Omega\end{array}$ & $\begin{array}{l}4 \mathrm{~L}- \\
\mathrm{GaN}\end{array}$ \\
\hline $\begin{array}{l}\text { Five- } \\
\text { level }\end{array}$ & GaN FET & $\begin{array}{c}2 \times 2 \| \\
\text { EPC } 2033\end{array}$ & $\begin{array}{c}2 \times 150 \mathrm{~V} \\
3.5 \mathrm{~m} \Omega\end{array}$ & $\begin{array}{l}5 \mathrm{~L}- \\
\mathrm{GaN}\end{array}$ \\
\hline $\begin{array}{l}\text { Seven } \\
\text {-level }\end{array}$ & GaN FET & $\begin{array}{c}2 \mathrm{x} \\
\text { EPC } 2022\end{array}$ & $\begin{array}{c}2 \times 100 \mathrm{~V} \\
3.2 \mathrm{~m} \Omega\end{array}$ & $\begin{array}{c}7 \mathrm{~L}- \\
\mathrm{GaN}\end{array}$ \\
\hline
\end{tabular}

The following diagrams (Fig. 3 and 4) show the conduction and switching losses $\left(\mathrm{P}_{\mathrm{VL}}+\mathrm{P}_{\mathrm{VS}}\right)$ for two-level and three-level inverters with different power semiconductors (Tab. I) as function of switching frequency. The induction motor is driven at nominal operation point. The switching losses increase linearly with the switching frequency, especially in the case of the two-level inverter with IGBT (2L-IGBT). In the threelevel inverter with IGBT (3L-IGBT), this switching frequency-dependent increase in switching losses is considerably reduced. Above $10 \mathrm{kHz}$ (at $25^{\circ} \mathrm{C}$ ) or $5 \mathrm{kHz}$ (at $150{ }^{\circ} \mathrm{C}$ ) lower semiconductor losses than with the twolevel inverter are produced. The wide-bandgap power semiconductors (SiC MOSFET, GaN FET) achieve an extreme reduction in switching losses in the three-level inverter. There are hardly any switching losses, so that very high switching frequencies (several $100 \mathrm{kHz}$ ) are possible. At low junction temperatures $\left(25^{\circ} \mathrm{C}\right)$, GaN FETs are more advantageous (3L-GaN), while at high junction temperatures $\left(150^{\circ} \mathrm{C}\right) \mathrm{SiC}$ MOSFETs generates fewer losses (3L-SiC). The lowest losses occur in the two-level inverter with $\mathrm{SiC}$ MOSFETs (2L-SiC), so that the energy efficiency of the two-level inverter can be significantly improved only by using $\mathrm{SiC}$ MOSFETs. In this case, however, the further advantages of the multilevel inverter technology would be lost. At $20 \mathrm{kHz}$ inverter switching frequency the power semiconductor losses of the threelevel inverter are $57 \%$ (at $25{ }^{\circ} \mathrm{C}$ ) or $56 \%$ (at $150{ }^{\circ} \mathrm{C}$ ) lower compared to the two-level inverter.

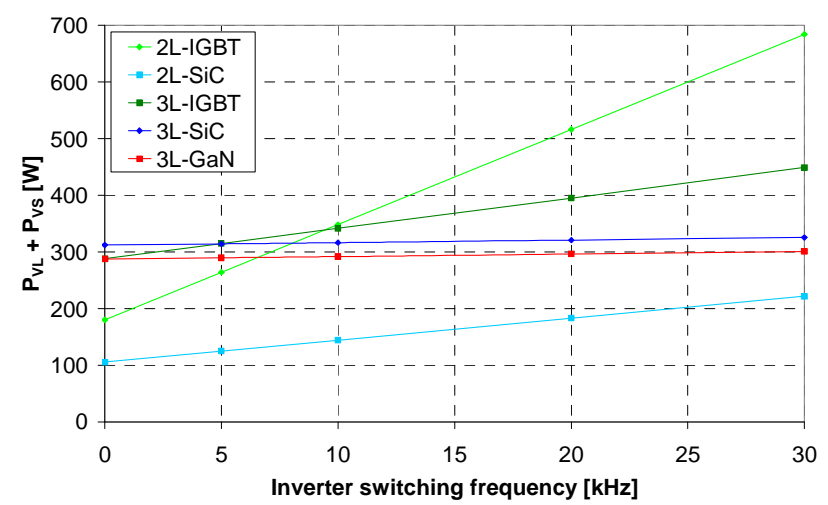

Fig. 3. Conduction and switching losses as function of switching frequency at nominal motor power and $25^{\circ} \mathrm{C}$ junction temperature.

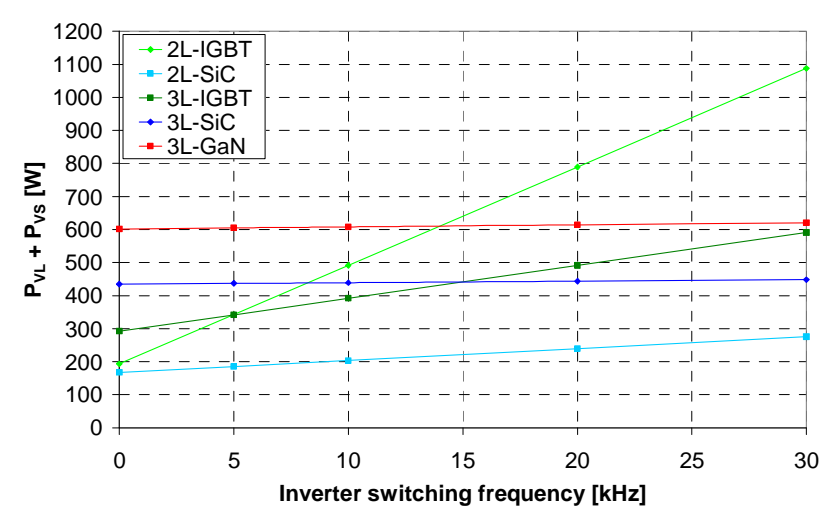

Fig. 4. Conduction and switching losses as function of switching frequency at nominal motor power and $150{ }^{\circ} \mathrm{C}$ junction temperature. 
The conduction and switching losses for the two-level, three-level, four-level, five-level and seven-level inverter (2L-IGBT, 2L-SiC, 3L-SiC, 3L-GaN, 4L-GaN, 5L-GaN, $7 \mathrm{~L}-\mathrm{GaN}$ ) are shown in Fig. 5 and 6 for an $11 \mathrm{~kW}$ induction motor as function of the motor power ( 0 to $125 \%$ ) at $25{ }^{\circ} \mathrm{C}$ or $150{ }^{\circ} \mathrm{C}$ junction temperature. The wide-bandgap power semiconductors have a clear advantage over the IGBT (2L-IGBT). In the three-level inverter, the $3 \mathrm{~L}-\mathrm{SiC}$ has the lowest losses at $25^{\circ} \mathrm{C}$ and the $3 \mathrm{~L}-\mathrm{GaN}$ at $150{ }^{\circ} \mathrm{C}$. The four-level inverter $(4 \mathrm{~L}-\mathrm{GaN})$ enables a further loss reduction compared to the threelevel inverter (3L-SiC, 3L-GaN), despite the unfavourable clamping diodes. Another significant loss reduction is achieved with the five-level inverter $(5 \mathrm{~L}-\mathrm{GaN})$; the total losses are even lower than with $2 \mathrm{~L}-\mathrm{SiC}$. However, the seven-level inverter (7L-GaN) hardly achieves any further loss reduction. With $5 \mathrm{~L}-\mathrm{GaN}$ and $7 \mathrm{~L}-\mathrm{GaN}$, the switching losses hardly play a role, so that the curves for $10 \mathrm{kHz}$ and $20 \mathrm{kHz}$ switching frequency are almost equal. The greatest loss reduction $\left(59 \%\right.$ at $25^{\circ} \mathrm{C}$ and $\left.150{ }^{\circ} \mathrm{C}\right)$ at nominal motor operation point is achieved with the two-level inverter only by replacing IGBTs with SiC FETs. By using the five-level inverter, a further slight loss reduction of $2 \%$ at $25{ }^{\circ} \mathrm{C}$ and $9 \%$ at $150{ }^{\circ} \mathrm{C}$ is possible. However, the seven-level leads to an increase of inverter losses.

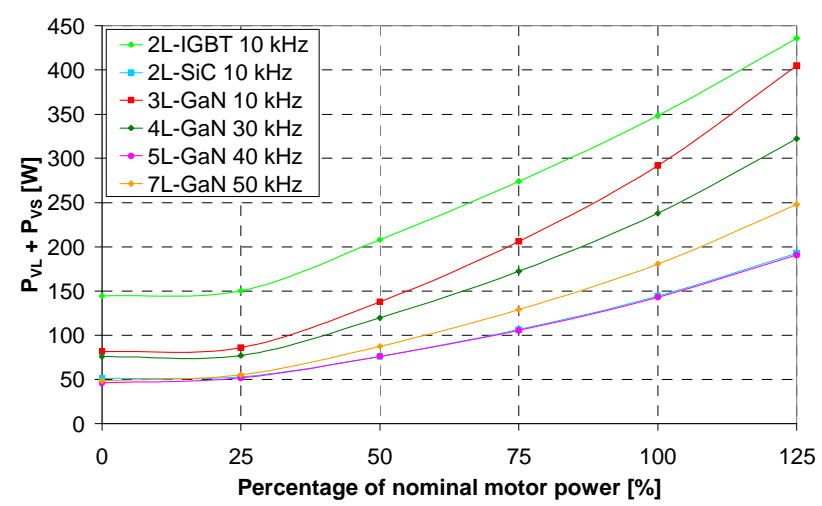

Fig. 5. Conduction and switching losses of the two-level, threelevel, four-level, five-level and seven-level inverter as function of motor power at $25^{\circ} \mathrm{C}$ junction temperature

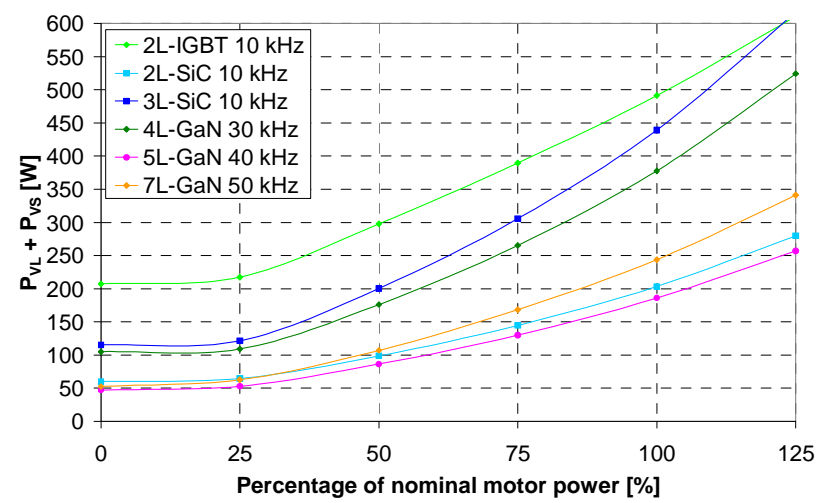

Fig. 6. Conduction and switching losses of the two-level, threelevel, four-level, five-level and seven-level inverter as function of motor power at $150{ }^{\circ} \mathrm{C}$ junction temperature

\section{B. Unequal Distribution of Losses}

The individual losses were grouped into the categories: conduction losses of the GaN FETs (PVLT), the free- wheeling diodes (PVLD) and clamping diodes (PVLCD) as well as total switching losses (PVS) and are shown in Fig. 7 and 8 at $10 \mathrm{kHz}$ switching frequency and $25^{\circ} \mathrm{C}$ or $150{ }^{\circ} \mathrm{C}$ junction temperature at different loads ( 0 to $125 \%$ ) of the $11 \mathrm{~kW}$ induction motor. The predominant proportion are conduction losses of the clamping diodes, with the four-level inverter this part is particularly high at around $75 \%$. The conduction losses of the freewheeling diodes and the total switching losses are negligible.

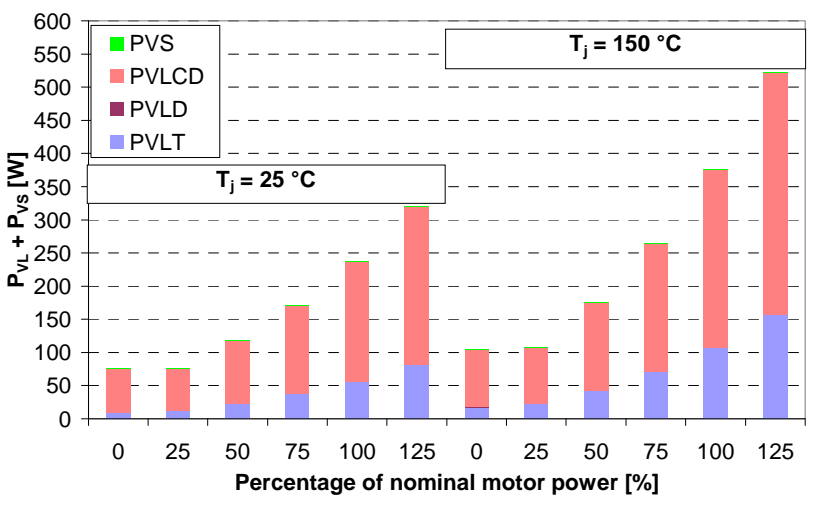

Fig. 7. Conduction losses of the GaN FETs, freewheeling and clamping diodes of the four-level inverter as function of motor power (11 kW induction motor)

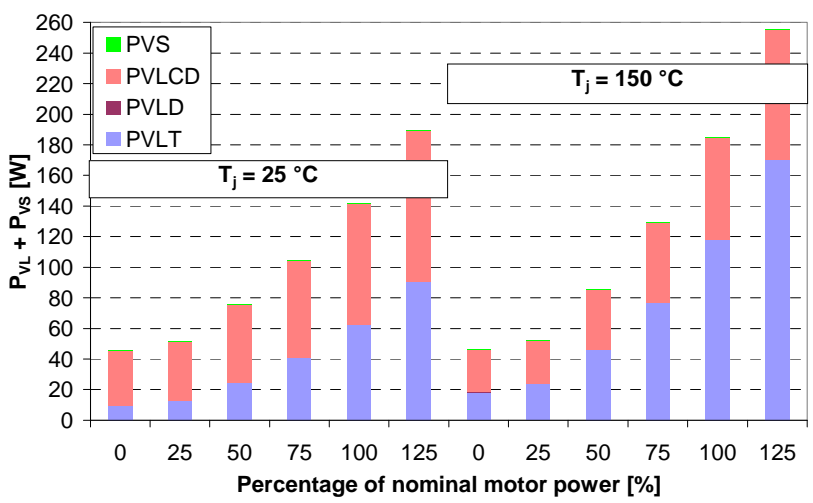

Fig. 8. Conduction losses of the GaN FETs, freewheeling and clamping diodes of the five-level inverter as function of motor power (11 kW induction motor)

\section{Inverter Output Filter}

\section{Analyses of Inverter Output Voltage}

Fig. 9 and 10 contain the output voltages of the two-level and seven-level inverter at $10 \mathrm{kHz}$ switching frequency. With a higher number of levels, the output voltage approaches the sinusoidal shape and the harmonic spectrum decreases. This visual impression is quantified by the total harmonic distortion content $\left(\mathrm{THD}_{\mathrm{u}}\right)$ according to equation (1), the indices OS denoting the harmonic component and GS denoting the fundamental component. The harmonic content indicates the quality of the inverter output voltage. The smaller the $\mathrm{THD}_{\mathrm{u}}$, the more sinusoidal is the voltage. The harmonic content depends on the number of inverter levels and the inverter modulation index (m) (Fig. 11). The higher the number of inverter levels, the lower the harmonic content. For example, with $\mathrm{m}=0.67$, the harmonic content is reduced by $84 \%$ for 
seven levels compared to two levels. The smaller the inverter modulation index, the higher the harmonic content. However, the harmonic content is not dependent on the switching frequency and not on the motor operation point.

$$
T H D_{U}=\frac{\tilde{U}_{W R a b O S}}{\tilde{U}_{W R a b G S}}=\frac{\sqrt{\tilde{U}_{W R a b}^{2}-\tilde{U}_{W R a b G S}^{2}}}{\tilde{U}_{W R a b G S}}
$$

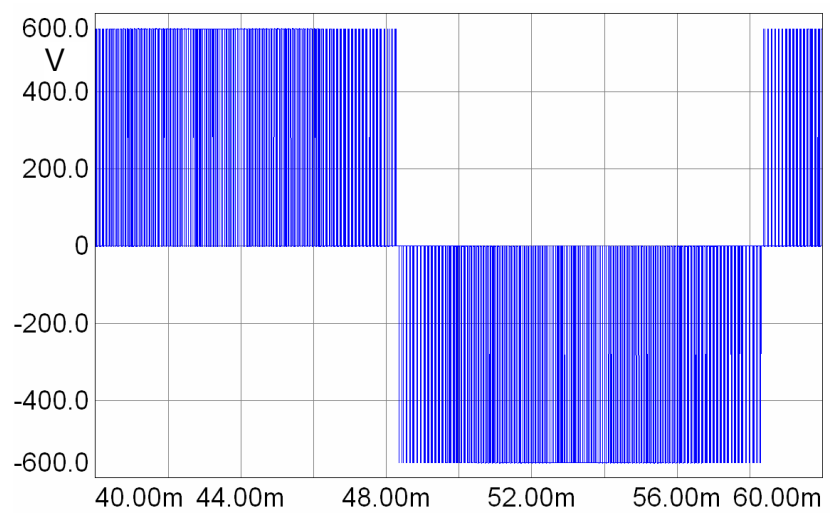

Fig. 9. Output voltage of the two-level inverter at $10 \mathrm{kHz}$ switching frequency $(\mathrm{m}=0,97)$

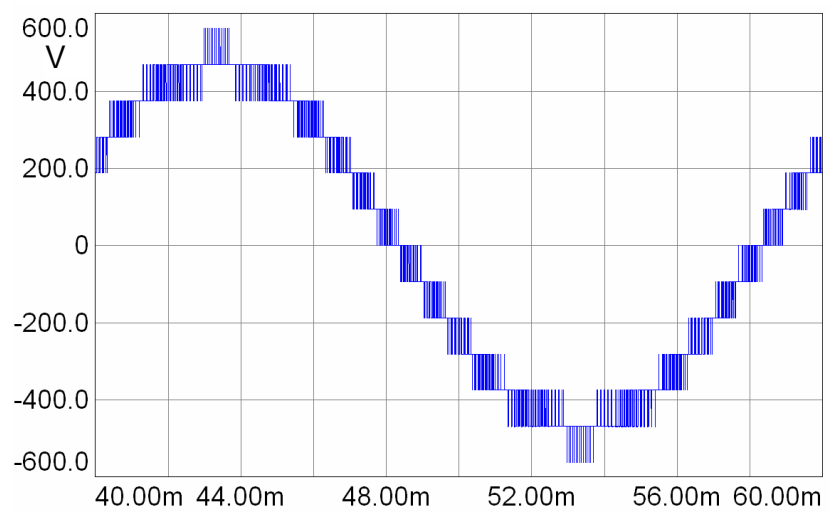

Fig. 10. Output voltage of the seven-level inverter at $10 \mathrm{kHz}$ switching frequency $(\mathrm{m}=0,97)$

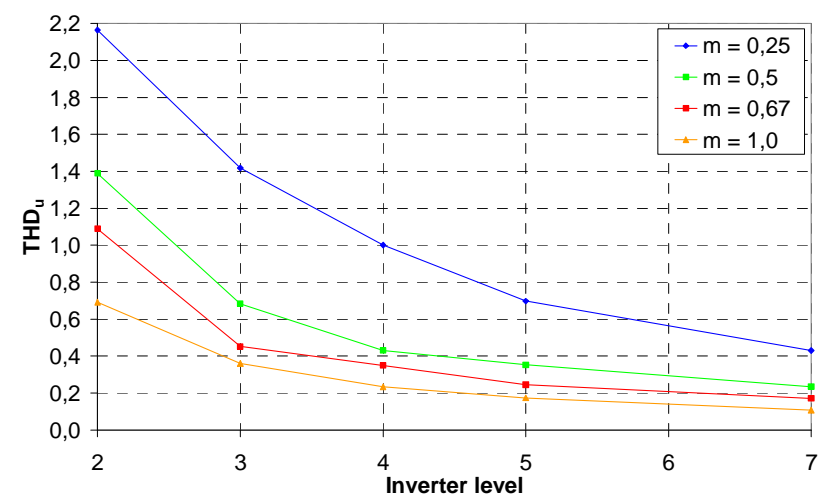

Fig. 11. Total harmonic distortion content of the inverter output voltage for different modulation index as function of inverter levels

\section{Filter Design and Losses}

Fig. 12 shows a three-phase inverter output filter (motor filter) that is installed on the inverter output terminals. It consists of the three-phase choke with an iron core and three AC capacitors. The three-phase choke covers the majority of the size, weight and losses. The associated electrical circuit consists of the inductors $\mathrm{L}_{\mathrm{F}}$ and the capacitors $\mathrm{C}_{\mathrm{FY}}$, which form a 2 nd order low-pass filter for the inverter output voltage. The natural frequency and damping result from equation (2).

$$
f_{0}=\frac{1}{2 \pi \sqrt{L_{F} \cdot C_{F Y}}} \quad ; \quad d=\frac{R_{F}}{2} \sqrt{\frac{C_{F Y}}{L_{F}}}
$$

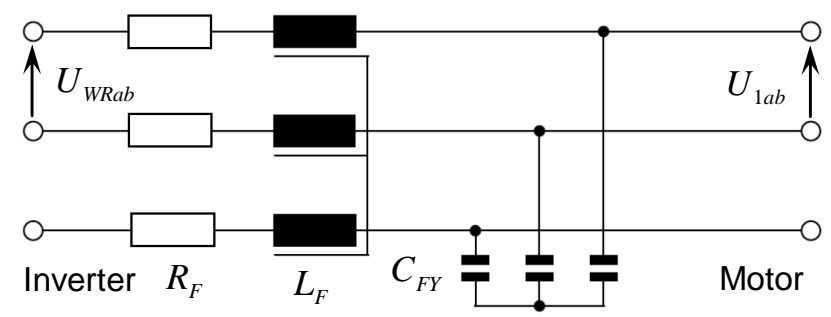

Fig. 12. Three-phase inverter output filter (motor filter)

The frequency-dependent attenuation (frequency response) between the inverter output voltage ( $\left.U_{\text {WRab }}\right)$ and the motor voltage $\left(\mathrm{U}_{1 \mathrm{ab}}\right)$ is shown in Fig. 13 for different inverter levels. The fundamental component of the inverter output voltage $\left(\mathrm{f}_{1} \leq 100 \mathrm{~Hz}\right)$ passes through the filter without amplification or attenuation. At the switching frequency of $10000 \mathrm{~Hz}(10 \mathrm{kHz})$, the required damping is marked. The higher the number of levels, the lower the harmonic content of the inverter output voltage, so that the required attenuation is lower. As a result, the natural frequency of the filter $f_{0}$ can be higher, which reduces the inductances and capacitors and the size of the filter.

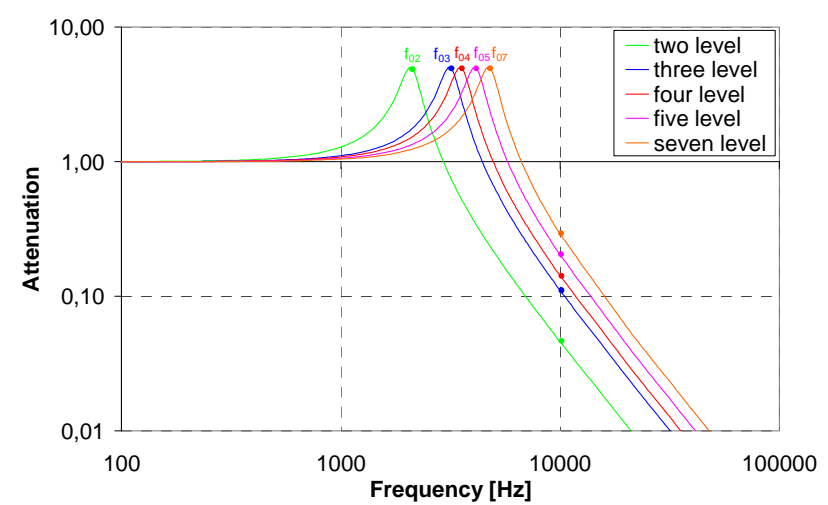

Fig. 13. Amplitude-frequency characteristic of the motor filter for different inverter levels

The required natural frequency of the filter depends on the number of levels and the switching frequency and is calculated according to equation (3). The harmonic content permitted in the motor voltage is usually $\mathrm{THD}_{\mathrm{u} \mathrm{ref}}=0.1(10 \%)$.

$$
f_{0}=\frac{f_{p}}{\sqrt{1-2 d^{2}+\sqrt{\left(1-2 d^{2}\right)^{2}-1+\frac{1}{|G|^{2}}}}} ;|G|=\frac{T H D_{u \text { ref }}}{T H D_{u}}
$$

For a motor filter for the $11 \mathrm{~kW}$ induction motor, Tab. II contains the values of the inductances $L_{F}$ and capacitors $\mathrm{C}_{\mathrm{FY}}$ for various inverter levels and switching frequencies. 
Table II. - Filter Design for Different Levels and Switching Frequencies

\begin{tabular}{|c|c|c|c|c|}
\hline level & $\mathrm{f}_{\mathrm{p}}[\mathrm{Hz}]$ & $\mathrm{f}_{0}[\mathrm{~Hz}]$ & $\mathrm{L}_{\mathrm{F}}[\mathrm{mH}]$ & $\mathrm{C}_{\mathrm{FY}}[\mu \mathrm{F}]$ \\
\hline two & 4000 & 1258 & 1.6 & 10 \\
\hline two & 10000 & 2900 & 0.69 & 4.33 \\
\hline three & 10000 & 4256 & 0.47 & 2.95 \\
\hline four & 20000 & 9428 & 0.21 & 1.33 \\
\hline four & 30000 & 14142 & 0.14 & 0.89 \\
\hline five & 40000 & 21535 & 0.093 & 0.58 \\
\hline five & 50000 & 26919 & 0.075 & 0.47 \\
\hline seven & 10000 & 6075 & 0.33 & 2.07 \\
\hline seven & 30000 & 18224 & 0.11 & 0.69 \\
\hline seven & 50000 & 30373 & 0.066 & 0.41 \\
\hline
\end{tabular}

The dimensioning of the three-phase choke was carried out with appropriate special software. Fig. 14 shows the calculated volume and weight. The three-phase choke amounts nearly $85 \%$ of the total volume and losses of the motor filter. By increasing the number of levels from two to five and the switching frequency from $4 \mathrm{kHz}$ to $40 \mathrm{kHz}$, the volume can be reduced by $86 \%$ and weight can be reduced by $78 \%$. A further increase in the number of levels and switching frequency does not result in any further reduction in volume and weight. The increase of levels and switching frequency leads to a continuous reduction of filter losses. By increasing the number of levels to seven and the switching frequency to $50 \mathrm{kHz}$, the losses can be reduced by $72 \%$.

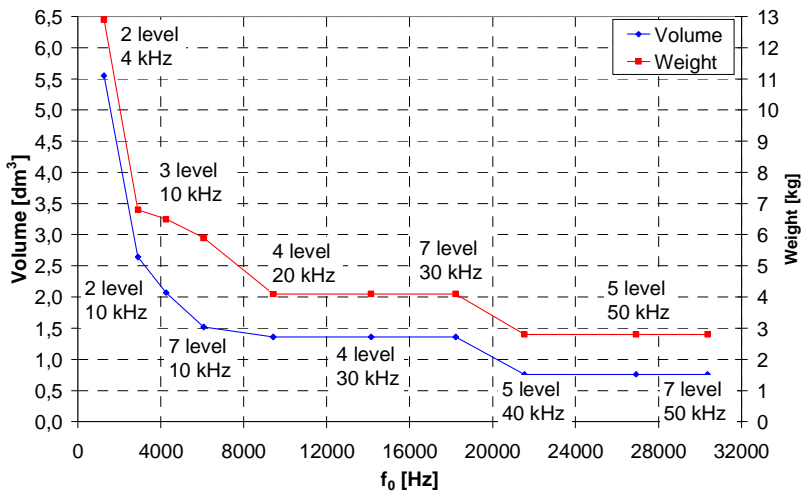

Fig. 14. Volume and weight of the three-phase choke for various inverter levels and switching frequencies

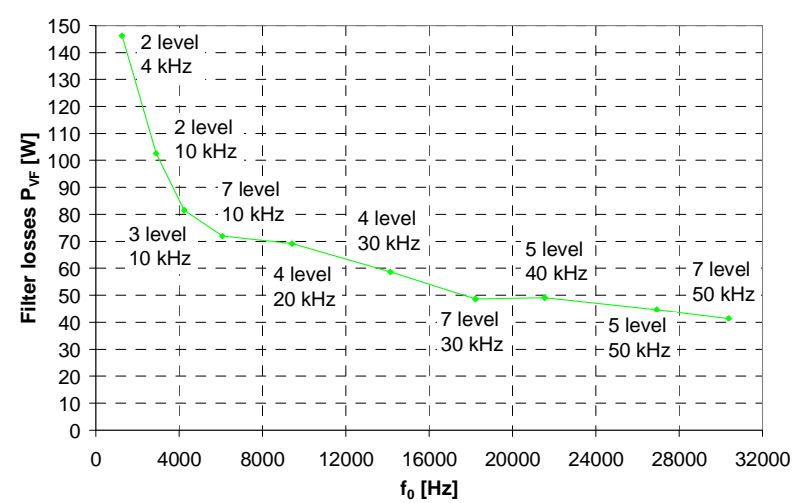

Fig. 15. Power losses of the three-phase choke for various inverter levels and switching frequencies

\section{E. Energy Efficiency of the Power Electronic System}

In Fig. 16 and 17, the energy efficiency of the power electronic system, consisting of multilevel inverter and the motor filter, for an $11 \mathrm{~kW}$ high-efficiency induction motor as function of the motor power $(0$ to $125 \%)$ at $25{ }^{\circ} \mathrm{C}$ or $150{ }^{\circ} \mathrm{C}$ junction temperature is compared with a conventional two-level inverter with IGBT (2L-IGBT). A considerable reduction in losses is already achieved with the two-level inverter by replacing IGBTs with $\mathrm{SiC}$ MOSFETs. A further slight reduction in losses is achieved by the five-level inverter $(5 \mathrm{~L}-\mathrm{GaN})$ with a switching frequency of $40 \mathrm{kHz}$. The seven-level inverter (7L-GaN) with a switching frequency of $50 \mathrm{kHz}$ increases the losses again slightly. Therefore the five-level inverter seems to be the optimum topology, as well as at $25^{\circ} \mathrm{C}$ and $150{ }^{\circ} \mathrm{C}$ junction temperature. Overall, by using the five-level inverter at a switching frequency of $40 \mathrm{kHz}$, the losses in the inverter and motor filter at nominal motor operation point are reduced by $57 \%$ at $25^{\circ} \mathrm{C}$ and $60 \%$ at $150{ }^{\circ} \mathrm{C}$ compared to a conventional two-level inverter with IGBT.

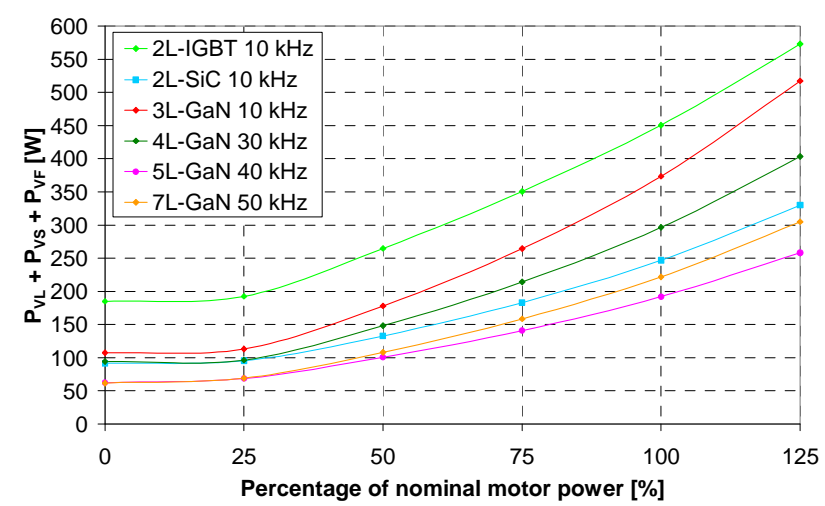

Fig. 16. Inverter and filter losses of the two-, three-, four-, fiveand seven-level inverter at $25^{\circ} \mathrm{C}$ junction temperature as function of motor power

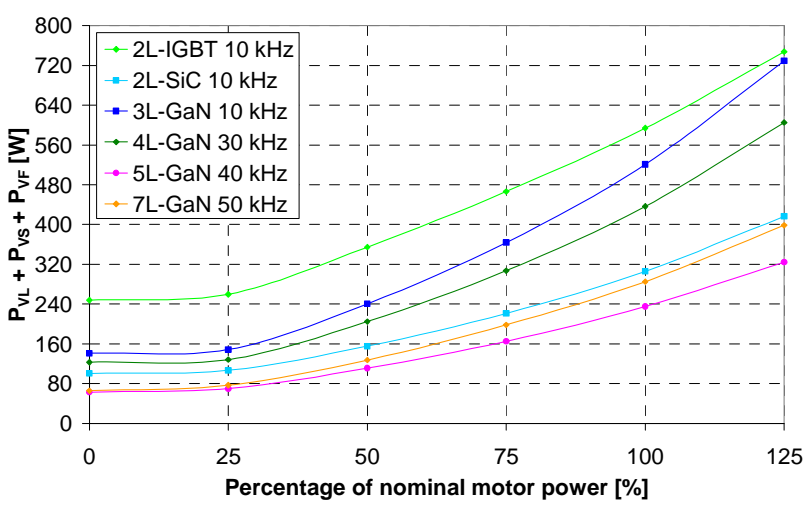

Fig. 17. Inverter and filter losses of the two-, three-, four-, fiveand seven-level inverter at $150{ }^{\circ} \mathrm{C}$ junction temperature as function of motor power

The following diagrams (Fig. 18 and 19) show the efficiency of the power electronic system as function of the motor power $(0$ to $125 \%)$ at $25^{\circ} \mathrm{C}$ or $150{ }^{\circ} \mathrm{C}$ junction temperature. At nominal motor operation point, the twolevel inverter with $\mathrm{SiC}$ FETs (2L-SiC) can improve the efficiency $\left(1.6 \%\right.$ at $25^{\circ} \mathrm{C}$ and $2.2 \%$ at $\left.150{ }^{\circ} \mathrm{C}\right)$. The fivelevel inverter with a switching frequency of $40 \mathrm{kHz}$ achieves an efficiency of $98.5 \%$ at $25^{\circ} \mathrm{C}$ and $98.1 \%$ at 
$150{ }^{\circ} \mathrm{C}$ in nominal operation point. Compared to the state of the art (2L-IGBT), this corresponds to an improvement of $2.1 \%$ at $25{ }^{\circ} \mathrm{C}$ and $2.7 \%$ at $150{ }^{\circ} \mathrm{C}$. In addition, the efficiency remains almost constant over a large load range between 25 and $125 \%$.

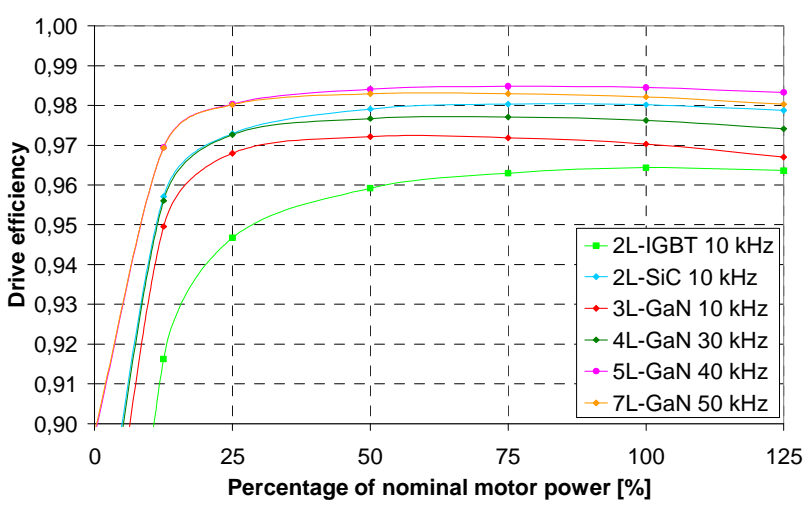

Fig. 18. Efficiency of the power electronic system with inverter and motor filter as function of motor power at $25^{\circ} \mathrm{C}$ junction temperature

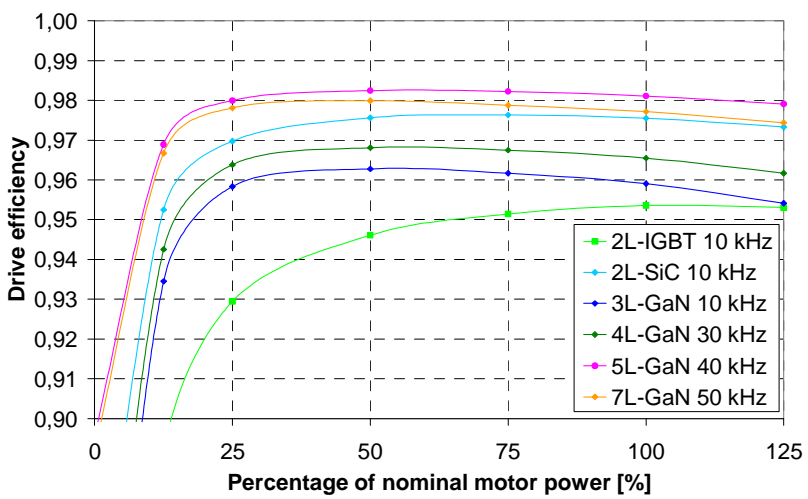

Fig. 19. Efficiency of the power electronic system with inverter and motor filter as function of motor power at $150{ }^{\circ} \mathrm{C}$ junction temperature

\section{Conclusion}

Low-voltage wide-bandgap power semiconductors (SiC MOSFETs, GaN FETs) are now available for multilevel inverters with 560 to $750 \mathrm{~V}$ DC link voltages. They have hardly any switching losses, so that very high switching frequencies (several $100 \mathrm{kHz}$ ) are possible. With a higher number of inverter levels, the size of the motor filter can be reduced. For the investigated $11 \mathrm{~kW}$ induction motor, the five-level inverter with $40 \mathrm{kHz}$ switching frequency is an optimum topology. Volume and weight of the motor filter can be reduced by $86 \%$ and $78 \%$ respectively. The overall efficiency of the power electronic system achieves $98.5 \%$ at $25^{\circ} \mathrm{C}$ and $98.1 \%$ at $150{ }^{\circ} \mathrm{C}$ junction temperature. Compared to the state of the art (two-level with IGBTs with $5 \mathrm{kHz}$ switching frequency), this is an improvement of $2.1 \%$ at $25^{\circ} \mathrm{C}$ and $2.7 \%$ at $150{ }^{\circ} \mathrm{C}$. Moreover, lower inverter power losses would lead to a reduction of cooling effort and to smaller inverter size. The application of multilevel inverters can make a contribution to efficiency improvement in electrical drives for new applications as e-mobility or renewable energy conversion.

\section{References}

[1] Floricau, D.; Gateau, G.; Leredde, A.; Teodorescu, R: The efficiency of three-level active NPC converter for different PWM strategies. European Conference on Power Electronics and Applications, Barcelona 2009, Proceedings on CD-ROM.

[2] Lidow, A.; De Rooij, M.; Strydom, J.; Reusch, D.; Glaser, J.: GaN Transistors for Efficient Power Conversion. Third Edition, John Wiley \& Sons Ltd. 2020.

[3] Ravyts, S.; Dalla Vecchia, M.; Zwysen, J.; Van den Broeck, G.; Driesen, J.: Comparison between an interleaved boost converter using Si MOSFETs versus GaN HEMTs. International Conference on Power Electronics, Intelligent Motion and Power Quality, Nürnberg 2018, pp. 647-654.

[4] Xu, J.; Chen, D.: A performance comparison of GaN EHEMTs versus SiC MOSFETs in power switching applications. Bodo`s Power Systems, June 2017, pp. 36-39.

[5] Lei, Y.; Barth, C.; Qin, S.; Liu, W.; Stichwell, A.: A 2-kW single-phase seven-level flying capacitor multilevel inverter with an active energy buffer. IEEE Transactions on Power Electronics, Vol. 32, No. 11, November 2017, pp. 8570-8580. 